\title{
Main concerns regarding in vitro fertilization techniques: results of a website survey
}

\section{Principais preocupações com relação às técnicas de fertilização in vitro: resultados de uma enquete online}

Edson Borges Jr., MD, Ph.D. ${ }^{1,2}$,Amanda Souza Setti, B.Sc. ${ }^{1,2}$,Daniela Paes de Almeida Ferreira Braga, M.Sc. ${ }^{1,2}$, Rose Marie Melamed ${ }^{2}$, Rita de Cassia Savio Figueira, M.Sc. ${ }^{2}$,Assumpto Iaconelli Jr., MD. ${ }^{1,2}$

\author{
${ }^{1}$ Instituto Sapientiae - Centro de Estudos e Pesquisa em Reprodução Humana Assistida \\ 2 Fertility - Centro de Fertilização Assistida
}

\section{RESUMO}

Introdução: As técnicas de fertilização in vitro pode se tornar um fardo ético, físico, psicológico e econômico. Este estudo foi desenhado para investigar algumas dessas preocupações em indivíduos participantes de uma pesquisa online. Métodos: Este estudo foi realizado em um centro de fertilização assistida privado. Indivíduos que acessaram o site do centro, desde abril de 2010 a agosto de 2012, foram convidados a participar de uma enquete. A enquete foi baseada em uma pergunta de escolha múltipla simples: "Qual é a sua principal preocupação em relação a submeter-se a um tratamento de fertilização in vitro?". Havia seis respostas disponíveis: (i) financeira, (ii) gestação múltipla, (iii) malformação na progênie, (iv) preconceito social, (v) religião e (vi) embriões supranumerários. Além disso, os participantes foram convidados a fornecerem seu sexo, idade e profissão. Resultados: Um total de 5.582 pessoas participaram da pesquisa, 994 homens e 4.588 mulheres. A média de idade foi de $34,1 \pm 9,6$ anos. A média de idade do sexo feminino foi de $33,6 \pm 7,6$ e a média de idade do sexo masculino $36,4 \pm 15,7$ anos. A principal preocupação em relação a submeter-se a um tratamento de fertilização in vitro foi financeira $(82,6 \%)$, seguido por malformação na progênie $(7,0 \%)$, gestação múltipla $(4,8 \%)$, embriões supranumerários $(3,3 \%)$, religião $(1,3 \%)$ e preconceito social $(1,0 \%)$. Conclusão: A conclusão deste estudo é que as questões financeiras são a principal preocupação em relação a técnicas de fertilização in vitro. Além disso, a tecnologia de reprodução assistida (ART) levantou complexas questões éticas, legais e sociais. A sociedade deve ponderar os benefícios contra os riscos e definir os limites para as disposições destas técnicas úteis. .

Palavras-chave: fertilização in vitro, injeção intracitoplasmática de espermatozóides, pesquisa

\footnotetext{
ABSTRACT

Introduction: IVF techniques may lead to ethical, physical, psychological, and economic burdens. This study was design to investigate some of these concerns in individuals participating in an online survey.

Materials and methods: This study was conducted in a private assisted fertilization center. Individuals that accessed the center's website, from April 2010 to August 2012,
}

have been asked to participate in a survey. The survey was based on a single multiple choice question: "What is your main concern regarding undergoing an in vitro fertilization treatment?". There were six available answers: (i) financial, (ii) multiple gestation, (iii) malformation in the offspring, (iv) social prejudice, (v) religion and (vi) supernumerary embryos. In addition, participants have been asked to enter their age, gender and profession.

Results: A total of 5582 subjects participated in the survey, 994 males and 4588 females. Mean age was 34.1 \pm 9.6 years. Mean female age was $33.6 \pm 7.6$ and mean male age $36.4 \pm 15.7$ years. The main concern regarding undergoing an IVF treatment was financial (82.6\%); followed by malformation in the offspring $(7.0 \%)$, multiple gestation $(4.8 \%)$, supernumerary embryos $(3.3 \%)$, religion $(1.3 \%)$ and social prejudice $(1.0 \%)$.

Conclusions: The conclusion of this study is that financial issues are the main concern regarding IVF techniques. In addition, assisted reproductive technology (ART) has raised complex ethical, legal and social issues. Society should weight the benefits against the risks and set the limits for the provisions of these useful techniques.

Key words: in vitro fertilization, intracytoplasmic sperm injection, survey.

\section{INTRODUCTION}

It is estimated that approximately one in six couples experience infertility problems at some point in their reproductive lives (Garceau et al.,2002). Since the introduction of in vitro fertilization (IVF) in 1978 (Steptoe \& Edwards,1978), the indications to start IVF treatment have been widened. In the early days, the main indication for IVF was tubal occlusion; nowadays, it is used for almost all categories of sub fertility diagnoses. Depending on the precise nature of the fertility problem, various IVF techniques are available to assist the 'infertile' patient to become pregnant and deliver a healthy baby. This includes conventional IVF and intracytoplasmic sperm injection (ICSI).

IVF interventions contain a number of stressful aspects, such as the daily injections related to pharmacological ovarian stimulation, blood samples, ultrasound scan, sperm sample from masturbation, administration of anesthesia, surgical oocyte retrieval and manipulation of oocytes, spermatozoa and embryos. In addition, conventional IVF and ICSI are costly, time-consuming processes. Therefore, these techniques might lead to ethical, physi- 
cal, psychological, and economic burdens (van Dongen et al.,2010). This study was design to investigate some of these concerns in individuals participating in an online survey. Its main focus will be on the main concern of entering the IVF treatment.

\section{MATERIAL AND METHODS}

This study was conducted in a private assisted fertilization center. Individuals that accessed the center's website, from April 2010 to August 2012, have been asked to participate in a survey. The survey was based on a single multiple choice question: "What is your main concern regarding undergoing an in vitro fertilization treatment?". There were six available answers: (i) financial, (ii) multiple gestation, (iii) malformation in the offspring, (iv) social prejudice, (v) religion and (vi) supernumerary embryos. In addition, participants have been asked to enter their age, gender and profession.

Data are expressed as mean \pm standard deviation. Data analysis was conducted using MINITAB 16 Software.

\section{RESULTS}

A total of 5582 subjects participated in the survey, 994 males $(17.8 \%)$ and 4588 females $(82.2 \%)$. Mean age was $34.1 \pm 9.6$ years. Mean female age was $33.6 \pm 7.6$ and mean male age $36.4 \pm 15.7$ years (Figure 1 ). The distribution of professions is showed in Figure 2.

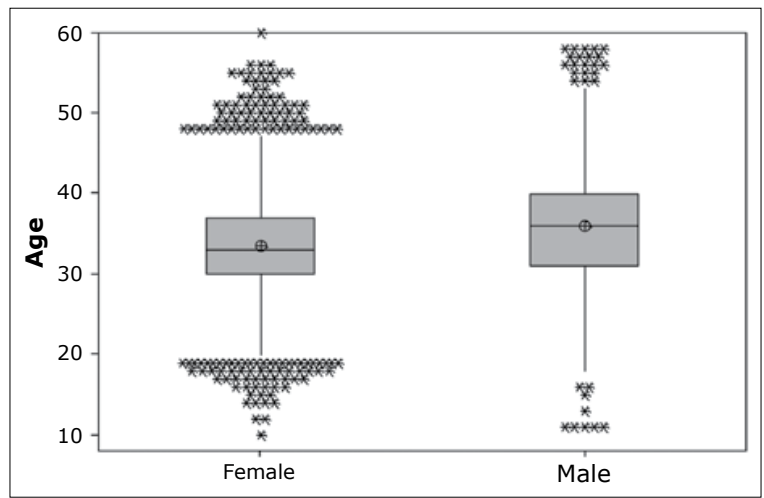

Figure 1. Box plot of participants' age

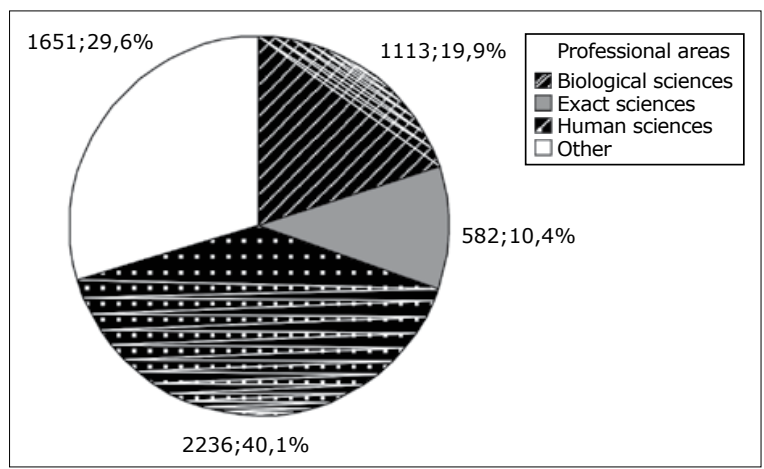

Figure 2. Participants' professional areas

The result of the survey conducted in 5582 males and females is showed in Figure 3 and 4 . The main concern regarding undergoing an IVF treatment was financial (82.6\%); followed by malformation in the offspring $(7.0 \%)$, multiple gestations $(4.8 \%)$, supernumerary embryos $(3.3 \%)$, religion $(1.3 \%)$ and social prejudice $(1.0 \%)$.

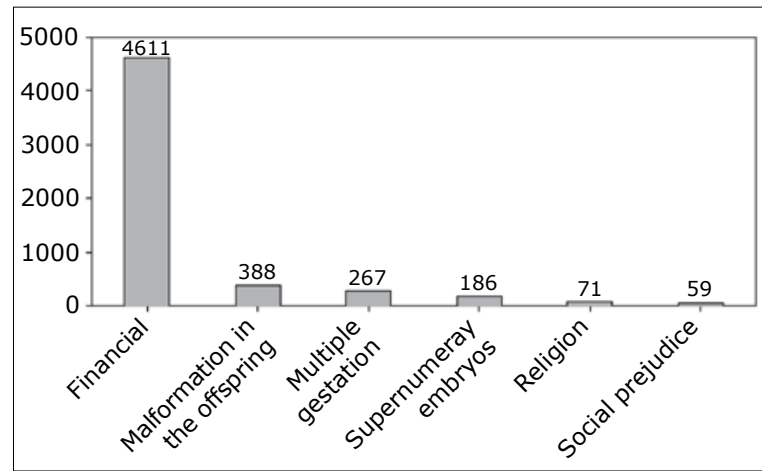

Figure 3. Result of survey

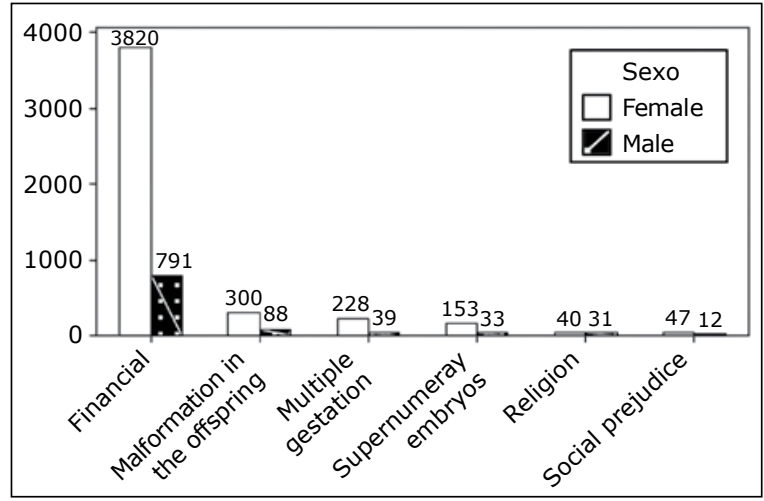

Figure 4. Result of survey by gender

\section{DISCUSSION}

Every day, approximately 500,000 people go online for the first time. It is estimated that $70 \%$ of people consider the internet indispensable (www.nic.br). At the moment, Brazil stands in fifth place among the 20 countries with the largest number of people connected to the World Wide Web, after Japan, India, the United States of America and China. In addition, the internet has become the third largest communication vehicle in Brazil, behind the radio and television. The percentage of Brazilians connected to the Internet increased from $27 \%$ to $48 \%$ between 2007 and 2011, reaching a record of 83.4 million in 2012 (www.nic.br). A total of $87 \%$ of Internet users make use of the Internet to research products and services and $70 \%$ trust in opinions expressed online (www.nic.br).

One of the most significant advances in survey technology in the twentieth century is the electronic survey. Web-based surveying is becoming widely used in social science and educational research. Moreover, web-based questionnaires have been widely used in several studies dealing with many different issues (Friberg et al.,2012; Iffland et al.,2012; Wei et al.,2012; Zimmermann et al.,2012).

Assisted fertilization treatments are emotionally and physically stressful and financially demanding. The aim of this survey was to investigate the main concern of entering the IVF treatment. Our result demonstrated that the main concern regarding undergoing an IVF treatment was financial $(81.6 \%)$; followed by malformation in the offspring, multiple gestation, supernumerary embryos, religion and social prejudice.

IVF treatments are costly technologies that involve medical appointments, drugs, ultrasounds and expensive labora- 
tory facilities. In Brazil, in vitro fertilization treatments and involved medications do not qualify for reimbursement. The cost of IVF treatment far exceeds the financial capability of most of couples, who are sometimes compelled to abandon their wish to procreate. In light of the increasing demand for infertility care, it is of utmost importance to consider cost-effective treatment options.

Couples desiring to have a baby through in vitro fertilization can spend months gathering information, diagnosing their infertility and discovering treatment alternatives. Because much of this research occurs online, assisted fertilization clinics would obtain new patients by providing the best information on their website, including disclosures of their results and rates of success.

It is important to emphasize that a survey of this kind is subject to certain methodological limitations, which need to be addressed. The results may have been influenced by patient self-selection because of the fact that a) not everyone is connected, so this survey method will not work with all populations (Dillman, 2000); b) even if connected, not all potential participants are equally computer literate (Dillman,2000); c) the majority of participants $(82.6 \%)$ are female; and d) the fertility potential of the participants is unknown.

The conclusion of this study is that financial issues are the main concern regarding IVF technique. In addition, assisted reproductive technology has raised complex ethical, legal and social issues. No other medical advent has ever caused so many disagreements among the scientists and the community as a whole. Despite the difficulties, the reproductive medicine has succeeded in establishing IVF and increasing its application. Society should weight the benefits against the risks and set the limits for the provisions of these useful techniques.

\section{Corresponding author}

Edson Borges Jr., MD, Ph.D

E-mail: edson@fertility.com.br

Address: Av. Brigadeiro Luis Antonio, 4545.

Sao Paulo - SP, Brazil. Zip: 01401-002

Phone: 3018-8181

\section{REFERENCES}

Dillman D, eds. Mail and Internet surveys -The tailored design method. New York: John Wiley \& Sons, Inc.; 2000.

Friberg P, Hagquist C, Osika W. Self-perceived psychosomatic health in Swedish children, adolescents and young adults: an internet-based survey over time. BMJ Open. 2012;2:e000681.

Garceau L, Henderson J, Davis LJ, Petrou S, Henderson LR, McVeigh E, Barlow DH, Davidson LL. Economic implications of assisted reproductive techniques: a systematic review. Hum Reprod. 2002;17:3090-3109.

Iffland B, Sansen LM, Catani C , Neuner F. Emotional but not physical maltreatment is independently related to psychopathology in subjects with various degrees of social anxiety: a web-based Internet survey. BMC Psychiatry. 2012;12:49.

Núcleo de Informação e Coordenação do Ponto BR [site in the internet] [updated 2013 Feb 4; cited 2013 Feb 28]. Available at: http:// www.nic.br/.

Steptoe PC , Edwards RG. Birth after the reimplantation of a human embryo. Lancet. 1978;2:366.

van Dongen AJ, Verhagen TE, Dumoulin JC, Land JA, Evers JL. Reasons for dropping out from a waiting list for in vitro fertilization. Fertil Steril. 2010;94:1713-1716.

Wei HT, Chen MH, Huang PC, Bai YM. The Association between Online Gaming, Social Phobia, and Depression: an Internet Survey. BMC Psychiatry. 2012;12:92.

Zimmermann A, Bernuit D, Gerlinger C, Schaefers M , Geppert $K$. Prevalence, symptoms and management of uterine fibroids: an international internet-based survey of 21,746 women. BMC Womens Health. 2012;12:6. 